\title{
Experimenting with a new tragic model: Elechi Amadi's Isiburu
}

\section{Omeh Obasi Ngwoke}

Omeh Obasi Ngwoke is a lecturer in the Department of English Studies at the University of Port Harcourt, Nigeria.

Email: ngwokeomeh@yahoo.com

DOI 10.17159/2309-9070/tvl.v.55i2.4948

\section{Experimenting with a new tragic model: Elechi Amadi's Isiburu}

Aristotle's Poetics has been an important resource for literary critics and theorists over the centuries from antiquity to contemporary times. However, despite its lofty status and acclaim the classical source material has also faced serious criticism especially concerning certain unrealistic and vague postulations made in it about tragedy. The most challenged postulations are those relating to the status of the tragic hero, his flaw, the emotions of pity and fear, and catharsis. Some of these "problematic" areas constitute the crux of Elechi Amadi's concern in "Gods and Tragic Heroes," an essay on which this article hinges. Re-examining some existing conversations on the subject and Amadi's charges against Aristotle, the essay affirms that tragedy is a flexible literary form and that Amadi, amidst his evaluation of Aristotle's enduring aesthetics, proposes a novel model in which hamartia and the emotional impact of the hero's fall on the audience are a function of an overarching supernatural activity in the tragic plot. Furthermore, the essay appraises the play Isiburu (1973) as Amadi's practical example of the proposed model. Keywords: Elechi Amadi, experimentation, form, poetics, tragic aesthetics.

\section{Introduction}

In an essay entitled "Gods and Tragic Heroes" published in 2003 in a volume entitled, Speaking and Singing: Essays and Poems, the renowned Nigerian writer, Elechi Amadi, takes Aristotle to task not just on some of the latter's postulations on tragedy, but also on his ironic misapplication of some of his own precepts concerning the same subject. Concluding the essay, Amadi proposes a novel critical model for tragedy-especially African tragedy - while admitting, however, that the Aristotelian canon, irrespective of its shortcomings, still stands the test of time. Hinged on insight from existing timeless conversations on the development and disparate functionality of the highly flexible literary form, this article seeks to re-examine Amadi's essay with a view to highlighting the deficiencies identified by him in Aristotle's timeless aesthetics and to establish through close textual evidence that his play Isiburu (originally performed and published three decades earlier, in 1973) is Amadi's experimentation with the new tragic model, which he proposes for the African tragedian.

\section{Critical responses to Aristotelian tragic aesthetics}

Tragedy and the aesthetics for its criticism are some of the major preoccupations of 
Aristotle's Poetics, the first book of literary theory and criticism (dated c. 335 B. C.). In fact, Aristotle's definition of drama derives from his discussion of tragedy, the drama type that is perhaps the philosopher's most revered and beloved. Tragedy, according to him, "is an imitation of an action that is admirable, complete and possesses magnitude; in language made pleasurable, each of its species separated in different parts; performed by actors, not through narration; effecting through pity and fear the purification of such emotions" (10). While the above definition encapsulates some of the basic characteristics of tragedy, the rest, as outlined in the Poetics, could be summed up as follows: a tragedy must dramatize a series of serious and important events in the life of a protagonist designated as the tragic hero; it has to be written in an elevated style marked by colourful language abounding in "rhythm and melody" (10); the hero must be a man of noble birth, or a man above the average and must represent virtue by being neither too good nor too bad; his actions must be characterized by an error of judgment called a tragic flaw or hamartia in Greek, which does not represent any form of depravity; this flaw characterized by free choice of action is what leads to his downfall and this misfortune is, according to Aristotle, not wholly deserved; before his fall comes a sudden revelation (anagnorisis) of certain aspects of his person of which he had been ignorant; the revelation brings about a reversal of his fortune (peripeteia); when he eventually falls, members of the audience who had been his admirers and followers are apprehended by the twin emotions of pity and fear; at the end, however, they experience catharsis which means a purgation (or purification) of the said emotions.

Although these prescriptions in the Poetics have, over the centuries, remained invaluable critical reference points to scholars engaged in the study of tragedy, concerns have arisen over the plausibility of some of them and their suitability to circumstances and milieus other than those of ancient Greece and the wider Europe. Consequently, "[t]here have been many attempts to adjust Aristotle's words to common [and practical] sense" (Muir 363). Sir Phillip Sidney, writing in 1595, argues that the emotional impact of tragedy on the audience does not wane with the ensuing catharsis as Aristotle suggests, but rather impresses on them serious morals relevant for societal development like making kings fear to be tyrants (45). Georg Hegel's 1835 theory of tragedy, rather than being based on the Aristotelian ideas of pity and fear and their purgation, is based on the dialectical notion that tragic conflict produces reconciliation and harmony irrespective of what befalls the protagonist (qtd. in Muir 366). In the twentieth century, the American playwright Arthur Miller describes the Aristotelian concept of the tragic hero as "archaic" and insists that "the common man is as apt a subject for tragedy in the highest sense as kings were" (744). His Death of a Salesman is a practical demonstration of his departure from the traditional Aristotelian norm. Kenneth Muir, whose general posture is defensive of Aristotle has had to remark that "One is tempted to suggest that the effect [...] of tragedy is to increase, 
not diminish our pity and terror-the compassion which is essential to the survival of humanity, and the terror that is akin to awe" (367). He thus questions Aristotle's idea of catharsis as the eradication of the tragic emotions from the audience. Elechi Amadi's journey on these paths is significant because of its newness and because of its focus on an aspect of the tragic enterprise that is not just different from those of other critics', but which seems to have been overlooked by Aristotle himself-that is, the presence and role of the supernatural in a tragic plot.

It is widely acknowledged that tragedy, just as the rest of the other major dramatic forms, has its roots in ritual; and because ritual is entwined with religion, it becomes obvious that the Aristotelian tragic canon, some of whose tenets scholars have challenged, is a product of the European cultural and religious world view just as it is certain that Amadi's proposed model for the African tragedian derives conversely from the African religio-cultural world view. It is, therefore, imperative at this point to examine the divergences in these opposing world views as a means of appreciating the different tragic aesthetics developed by the two scholars and of situating the different canons within historical and ontological contexts.

\section{Tragedy as a ritual-based form}

There is an obvious difference in the religio-cultural world views of Europe and Africa, and this has some implications for the kind of ritual-based drama that is and should be produced in these milieus. While different scholars have commented on the phenomenon of the African world view, Wole Soyinka is perhaps the one who has best conceptualized the dichotomy between the African and European world views. $\mathrm{He}$, in the first chapter of Myth, Literature and the African World, makes a comparison between ancient Greek and Yoruba approaches to oracles and divine intervention to analyse African literary works that are inspired by ritual. Greece and the Yoruba kingdom become representative of Europe and Africa. Soyinka speaks of cosmic unity as the mainstay of the African world view, and this, by his assessment, refers to the primordial close and harmonious relationship that exists among all creatures in the cosmos, including mortals and such other immortal and higher beings as the gods, spirits and ancestors generally referred to as the supernatural (2-3). Corroborating this view, Obi Maduakor notes that the African world view thrives in "the union of divine and human essences in man and god, the replenishment and continuance of which guarantees the unity of being in both" (305). This union is made possible because of what Zulu Sofola observes as the belief in Africa that "all creatures, all things, including humans, are endowed with the same Supreme Energy, all creatures are essentially one and the same" (qtd. in Reiss 507).

Conversely, the European world view, Soyinka avows, is that in which the bond between the mortal and the immortal and indeed forces within the universe has been severed. He notes that in the western world as opposed to the African, certain 
extraneous practices and belief systems-like the Platonic-Christian culture and Buddhism-which crept into the primordial religio-cultural consciousness of the people very early in their history have pushed the gods away from the earth, thus making them recede far beyond territories where humans can venture (3). Thus, while in Africa humans interact closely with their gods and can engage the gods in mystical negotiations over concerns like predestination and divine service, such mutual interaction is entirely absent in the European world where the decision of the gods concerning mortals is entirely non-negotiable. Kennedy Chinyowa puts the harmonious African situation succinctly when he asserts that in most African traditions, people "believe that they can plead, question and dialogue with the forces that govern and control their lives" (qtd. in Reiss 521). The point being made here is not that African gods are incapable of upsetting mankind and thus undermining their well-being, but that African gods are amenable to propitiation. The Greek/European gods, by Soyinka's assessment, lack this ethical obligation (14).

Timothy J. Reiss presents what is perhaps a more detailed description of the European world view which, wittingly or unwittingly, influences its writers' tragic vision. In an essay entitled "Using Tragedy Against Its Makers: Some African and Caribbean Instances", Reiss underlines some of the high points which have been encapsulated as follows: One, the European culture forces an impossible division between humans and the divine, other human groups, each other, and the material world; and this division is erroneously regarded by Europeans as universal (506). Two, this division causes the European man not to assume responsibility for his own actions and their consequences, but to blame the gods for his woes-this is why Oedipus in Oedipus Rex is quick to blame Apollo for his agonies (506). Three, the Western sense of "self" is an individual facing a greater divine, social, or political whole; a man in an anguished conflict with the divine, etc. Reiss argues that Western tragedy offers this separated (scythed) sense of human life (506).

The European situation is obviously why neither Oedipus' parents nor the priest, Tiresias (or even the hero as a young man) could negotiate his fate with the gods, leading therefore to the fulfilment of his destined doom. It is, therefore, clear that this perceived gulf between humans and the gods is responsible for the exclusion of the latter in European tragic aesthetics like Aristotle's Poetics although the immediate targets of the philosopher were tragedies predicated on predestination like the famous Oedipus Rex. Given the role of the supernatural in matters of predestination and indeed in most classic European tragedies, one would have expected that the gods would feature in the aesthetics of that drama type, especially in relation to the principle of hamartia. But, this, unfortunately, is not so. Interestingly, this lacuna is part of the concerns of Amadi in the essay on which this article partly hinges.

Europe, especially Greece, is believed, as already noted, to be the ancestral home of tragedy. Therefore, tragedy is one of her exports to the wider world. In this section, 
I attempt to examine the differences between the conception and role of tragedy in Europe and in cultures other than Europe, especially Africa, using Reiss's already cited essay as a guide. The main concern of Reiss in the essay is to explore the implications of the intricate journey of tragedy from its European provenance to Africa and the Caribbean. According to him, the European makers of tragedy had the following imperialist views and conceptions about the drama type: the first is that tragedy (as conceptualized by Aristotle and Nietzsche) was a westernized concept/practice which was a mark of sophistication (508); the second is that non-Europeans did not have tragedy because of their lack of sophistication (508); and the third is the Aristotelian belief that the performance of tragedy by non-Europeans was a corrupt performance handled by amateurs (508). Consequently, Reiss argues that the Western culture uses tragedy to grasp and control other cultures, but that the Caribbean dramatist Walcott urges the use of tragedy to turn that grasp (510).

The implication and consequence of Walcott's position is that non-European cultures have developed a different conception of tragedy, which Reiss believes consists, among other things, in using tragedy against its makers. One of the key means of doing this, in Reiss' assessment, is by the adaptation of European tragedies into African or Caribbean contexts, domesticating and manipulating them to serve the purposes of these Europe's "others" - purposes grounded in their belief system, culture and tradition. The scholar observes that Soyinka has done this with the Bacchae of Euripides, Ola Rotimi with The Gods Are Not to Blame, Efua Sutherland with Edufa, 'Zulu Sofola with Wedlock of the Gods, Ama Ata Aidoo with Anowa, etc. (Reiss 510-26). Another means is by creating tragedies which are truly African (or Caribbean as the case may be) in conception by which is meant tragedies that dramatize the contemporary socio-political and economic realities of these societies. Personalizing the thrust of the second method, Aimé Césaire asserts as follows in 1966: "my theatre is above all a political theatre because the major problems of Africa are political problems" (qtd. in Brichaux-Houyiux 12). This harks back to the idea of commitment in literature, which is necessary for the growth of the so-called developing nations that cannot afford such a western luxury as individualism in dramatic conception. Consequently, the African/Caribbean tragedy is, according to Reiss, a new idea of tragedy rooted in socio-political realities and attitudes towards them as shaped by cultural contexts (507).

Some of the tragic socio-political and economic realities of Africa dramatized in their plays could be summed up under colonization and its horrors, conflicts that weakened African cultures before colonialism, struggles of cultural values often involving failures of combative will or action, neo-colonialism characterized by crimes and corruptions of the African elite, etc. These are realities which Reiss observes as having formed narrative patterns in the African tragic scene (514). But, whether in the adaptation of a European prototype or in creating an independent tragedy, the 
African tragedian always tries to tailor his work towards a heroism that rather than serve the hero's personal interest as in the European examples already mentioned, serves the interest of his society. This, according to Reiss, is why unlike Sophocles who presents an Oedipus that had a lone defeat of a predatory Sphinx, Rotimi in his adaptation of the play presents an Odewale who is on a mission to defend his people (519). Still according to Reiss, Michael Etherton notes that Rotimi considers Odewale's mission as a divine one, but one in which the hero had a choice and as such bargained with the gods on the focus of his mission (518-9). This privilege of negotiating with the gods at the point of deciding a hero's divine earthly mission is part of what Chinyowa means by African tragic heroes being able to "plead, question and dialogue with the forces that govern and control their lives." Odewale is thus believed to have made, in the land of spirits, the choice of defending his people in the human world. This accounts, therefore, for the title which clearly absolves the gods of the agonies that Odewale goes through in the course of the play's tragic plot development.

\section{Amadi's prescriptions for the African tragedian}

As has been mentioned, Amadi admits in his essay that Aristotle's postulations in the Poetics concerning tragedy remain valid reference points to date to creators and critics of that drama type. However, Amadi's contention is with some of the most important and basic prescriptions, which he finds erroneous as their application in the analysis of Oedipus Rex by Aristotle entails contradictions. These are prescriptions involving the tragic hero's flaw and the twin emotions of pity and fear. Amadi observes that Aristotle insists on the following: the tragic hero's fall from glory to misery should be due "not to depravity but to some great error" in him that makes his exercise of his freedom of choice culminate in a tragic fatality; this fall should elicit in the audience pity and fear-pity because the hero should ideally be "better than the average" and as such undeserving of a misfortune, and fear because he is someone like us. Questioning the validity of the above postulations, Amadi reexamines Oedipus Rex and some of the major tragedies of Shakespeare like Macbeth, Hamlet and Romeo and Juliet and observes, contrary to the critics of these plays including Aristotle himself on Oedipus Rex, that the plays do not adhere strictly to the Aristotelian prescriptions. Amadi notices, for instance, that the heroes of the above prototype plays lack a tragic flaw in the sense that Aristotle delineates it. The heroes in these works, rather than being the architects of their own actions, are controlled by higher beings and so cannot be held responsible for their own downfall. Each of the heroes-Oedipus, Macbeth, Hamlet, and Romeo-is, according to Amadi ("Gods and Tragic Heroes" 64), propelled by some supernatural force(s) like the gods in Oedipus Rex, the witches in Macbeth, the ghost in Hamlet and fate in Romeo and Juliet, rather than by an Aristotelean "tragic flaw" of character. 
Concerning pity, Amadi's contrary response is that the fall of any human, whether highly or lowly placed, elicits pity because of the empathy that exists among humans; and regarding fear, he insists that the emotion cannot be evoked in the audience if the cause of the hero's fall is simply an error of character, which is as explicable as it is predictable given the audience's pre-knowledge of such faults in the hero; moreover, the audience are unlikely candidates for such a disaster since they may not possess such traits. Hence, Amadi insists that fear can only be aroused in the audience if the hero falls by some strange and mysterious circumstances attributable to powers stronger than them and obviously capable of harming them (Amadi, "Gods" 68-9). Consequently, he proposes a novel but hybrid tragic aesthetic especially for the African tragedian in which the two points of interest-the flaw of the tragic hero and the emotions of pity and fear-are entwined. This is a proposal that does not attempt to jettison the canonical aesthetics of Aristotle, but which tries to build on its perceived deficiencies to formulate a model that is at once universal and African in conception. It is a proposal that insists on relinking tragedy with its ritual roots, dramatizing terror-evoking struggles between the mortal hero and immortal beings.

Therefore, in his proposed model, Amadi places the supernatural very close to the centre of tragedy, second in importance only to the tragic hero himself, but without whom the hero's role as the tragic protagonist cannot be fully realized. The implication here is that the supernatural element becomes a real and major character whose role is intertwined with that of the hero to mastermind his fall. Amadi's proposal is therefore captured in the following statements, which while forming the summation of his arguments in the essay, represent his novel aesthetics for tragedy:

Firstly, while the misfortune of a hero can evoke pity, it generates fear usually if it is inexplicable, mysterious or associated with the supernatural, be it fate, spirits or gods. Secondly, the human instinct for the supernatural is powerful and ever present and is therefore a necessary ingredient in the full realization of tragedy.

Thirdly, for legal and penal purposes we have to assume that we act out of our own volition all the time; but in practical living, in drama and in fiction, we must allow that now and then events move beyond our control and freedom of action appears illusory. What are the implications for African literature? In Africa, religion, both native and imported, and the supernatural form very important aspects of our lives. So while the Aristotelian model of the tragic hero remains a classical reference point, we should consider other models and pay some attention to our interactions with "a greater power than we can contradict." (68-9, my emphasis)

Implied in the above is Amadi's abhorrence of a tragedy that is flagrantly built around un-terrific and less mysterious social, political or economic conflicts of mere mortals. This explains why of all his plays, Isiburu is the only one he considers a tragedy. The rest, by his reckoning, are not fit as tragic plots as they are purely social in con- 
ception and devoid of conflicts involving a human hero and a supernatural force.

\section{Isiburu as a tragedy}

The primordial African world of cosmic totality predominates Amadi's early works including Isiburu. This is a world of free association between natural and supernatural beings. In this world, the gods live among men as it were, and both interact based on such mutual respect that thrives between a conscientious master and a dutiful servant. While stressing this point about the world of Amadi's early works, the Nigerian scholar-cum-politician, Obi Wali, draws something of an analogy between the traditional European and African societies regarding the gods and their relationship with humans. According to him:

"As flies to wanton boys are we to the gods, they kill us for their sport," so exclaims Gloucester, in Shakespeare's King Lear. This portrays a rather frivolous relationship between the gods and human beings. Elechi Amadi's concept of this relationship is a far more serious one. In the society with which he pre-occupies himself in his works, there is strictly no demarcating line between the two worlds. (29)

Of course, in the world of Amadi's art, the gods exert enormous influence on their mortal protégés who are ever willing to live by the gods' precepts which are often geared towards the latter's advantage in terms of guidance, protection, procreation, a bountiful harvest, etc.

Needless to say, despite this seeming harmony, there could arise moments of friction that may result in expiable and inexpiable consequences like affliction and death. In all, the privilege which the African enjoys of pleading, questioning and dialoguing with his guardian supernatural forces remains intact, but this is not to be taken for granted neither does it in any way place humans on the same pedestal with the supernatural forces. Final decision on any subject, irrespective of the interactive procedures that may be initiated by humans, remains the prerogative of the gods. Therefore, in the world presented by Amadi in his tragic works (prose and drama alike), man remains "the biggest joke in the galaxy," because "like laboratory rats in a huge cage, we react just the way the Master Scientist wants us to react" (qtd. in Osofisa 33); or as Femi Osofisan puts it in a tribute to Amadi at age 55:

In all his works, his novels and plays, you close the book literally covered in cold sweat, terrified by the immense and inexorable power of the gods. Man is pitifully diminished. Whatever he tries, he fails, for all his effort at freedom turns out in the end, like in Greek Mythology, to be only a further step towards entrenching himself in the tedious web woven by the unseen gods. Life is cruel, to be a man is to be victim. (33)

Suggested in the above is that Amadi, despite this inequality between humans and the supernatural, gives his protagonists the opportunity to struggle against the 
forces over that which they believe in. "Their very struggle" writes Eko, "is thus a confirmation that man has and can exercise his will power. It is a protest against the forces, a refusal to surrender until absolutely crushed" (3).

European gods do not share with their human protégées the kind of relationship that their African counterparts share. In the African world, man can negotiate the decision of the gods concerning himself, and he may succeed or fail in causing the gods to change or adjust such decisions. Just as the format for the negotiations differs, the response of the affected human to certain unfavourable decisions of the gods also differs. When man succumbs to these unfavourable divine decisions of the gods there is peace, but when he challenges them conflict ensues, and, of course, the end is disastrous for him because he is a mismatch in a fight against the immortals.

As already noted, Amadi has no problem with the rest of the Aristotelian codes on tragedy except those that relate to hamartia and the twin emotions of pity and fear. This section, therefore, tries to show how Isiburu adheres to the unquestioned Aristotelian principles. Isiburu's plot is serious and important. Its seriousness rests firstly on the conflict of interests between the god, Amadioha, and the mortal, Isiburu. The protagonist challenges the decision of Amadioha, a highly dreaded and revered god among the Ikwerre of the Niger Delta, by refusing to immediately assume the role of chief priest to the god, even though the god has ordained him to that role through an oracle. The choice of a new chief priest to Amadioha is a serious matter and the chosen one's refusal to take immediate responsibility is a dangerous issue. The gods do not condone such impudence from mere mortals. The seriousness of the matter is heightened by the traditional Ikwerre society's perception of humans' relationship with their gods and particularly by their knowledge of the fierceness of the god in question. In Ikwerre land, just as in many other traditional African societies, the lives of human citizens are intertwined with those of their gods and the resultant relationship is that of the keeper and the kept. The gods are believed to control and oversee the affairs of men and disloyalty to them is considered a serious offence punishable even by death. The characters in Isiburu are aware of the grave danger hanging around the errant hero's neck, hence Isiburu as well as the incumbent chief priest, Agbarakwe, is troubled, for, according to the latter, Amadioha's "choice is so definite and irrevocable" (Isiburu 7).

The entire process involved in the hero's preparation for the seventh battle accounts partly for the seriousness of the plot. It involves the procurement of the most potent wrestling charm needing human sacrifice at far away Eluanyim, the dwelling place of the most powerful of dibias who drink through their noses and imbibe snuff through their eyes (Isiburu 10). Enmeshed in these events is the ironic contest between Uzo (a former prince but now a slave to Isiburu) and his master, Isiburu, for the love of Mgbeke (a slave woman betrothed to Uzo and who alone knows the way to Uzo's homeland and on whom he depends both for marriage and for going 
home upon manumission) which is heightened by Uzo's secret and fierce plot to kill Isiburu. While, for example, Isiburu is away on the fortification mission in company of Mgbeke, Uzo, according to a stage direction, "pauses and thinks, and the expression on his face changes from one of sorrow and doubt to one of anger and resolution"; and then his resolution is: "Blood for blood, I say! / It is the way of the gods; / He who creates a corpse / Shall himself become a corpse" (Isiburu 19).

The plot's seriousness climaxes in the hero's sudden realization, upon his triumphant return, that he has spiritually been killed by Uzo who had smashed his Pot of Life-a sacred vessel that holds the secret of Isiburu's success in wrestling bouts and the very essence of his life as a traditional man. The fatality inherent in the smashing of the pot is eloquently captured by the sudden fear that grips the hero upon noticing the broken pot and by his consequent words laden with regret, anguish and a tone of finality:

ISIBURU: [Turns round and sees Uzo and the broken Pot of Life. He gasps with fear and ap-

proaches the wreckage slowly, then he laughs hysterically.]

"The crab swam through mighty oceans

But succumbed to woman's pot of soup"

A wag once said so and I laughed

Drowning my doubts in a keg of wine,

But how true! (Isiburu 22)

While the above revelation marks the play's climax and the beginning of the reversal of the hero's fortunes, it squirms with the irony of human life. Man is often not destroyed by the greatest of his challenges, but by the very insignificant ones. As the greatest wrestler in Ikwerre land and beyond, Isiburu had defeated many strong oppositions, but an ordinary slave takes his life by a seemingly simple act of smashing a pot, and right at the hero's shrine at home.

Concerning language, Amadi's psychological indebtedness to the old canon of Aristotle and indeed Shakespeare is apparent. Isiburu is written in language depicting distinct and varying beauties, qualities which, according to Aristotle, represent "rhythm and melody" (10). Like the classical and Renaissance tragedians, Amadi seems to believe in the option of poetry as vehicle of tragic action. Therefore, Isiburu is written in verse.

In status, the eponymous hero, Isiburu, matches the classical prototype by being a wrestling champion and, as such, a man above the average. He possesses traits requisite of a hero, one of which is nobility. In her summation of the personality of Isiburu, Eko identifies the following heroic qualities of his: discipline, courage, fairness, desire for excellence and compassion (156). While the rest of the qualities are expected of every hero, that of fairness relates to the specific prescription by Aristotle which says that the hero must be neither too good nor too bad, hence he must be 
a man of virtue. As a revered wrestling champion who has held sway in that position for six good years, Isiburu is larger-than-life and so ranks among such classic examples as Oedipus, Macbeth and Hamlet. Like them, Isiburu is a rallying point for his people who adore him and identify with his progress; in fact, he is to his people Isiburu Ekperi!

Tough Grass of the Great Ponds!

Azo Dimgba!

He who carried high his opponents

And flung them at the onlookers

The cat whose back disdained the ground,

He who killed and called for vengeance. (Isiburu 28)

Isiburu has flaws in the true Aristotelian sense. One of his flaws is excessive kindness, which many characters agree is the remote cause of his death. One of the village elders, Wegwu, is categorical about this when he laments over the hero's corpse thus: "As too much kindness / Has ruined you in this trip, / In the next you will be wiser" (Isiburu 30).

The hero's kindness manifests itself at different occasions in the plot and the account of this is given by different characters: by Mgbeke when Isiburu seeks to take her in: "[...] Your kindness too has gone beyond / What men are wont to offer their slaves" (Isiburu 13), and by the village elder, Wegwu, while making the already cited lamentation over Isiburu's corpse. Isiburu's kindness is a defect because it is excessive; he extends it beyond proportion, thus leaving room for its coming back to haunt him. It is on record that Isiburu had saved the life of Uzo four times (Isiburu 15) when the latter could have been used to bury the corpses of chiefs or any such personality as tradition demands (ironically, it is the same character that eventually kills him); and that of Mgbeke two times, the second being when he refused to sacrifice her as a prerequisite for obtaining a potent charm for the seventh championship.

The hero's second and third flaws are those of vaulting ambition and stubbornness both manifesting themselves in his refusal to take immediate responsibility at the shrine of Amadioha as Chief Priest, a responsibility that could have averted his eventual death. Like most classic tragic heroes, Isiburu is ignorant of certain lifethreatening situations around and about him. He is unaware of Uzo's plot to kill him and like other tragic heroes the revelation comes very late, when he is on the brink of death.

As a departure from Aristotle, Amadi proposes the introduction of a supernatural character in the plot of a tragic play, who should mastermind the tragic hero's fall to 
make it mysterious and capable of evoking pity and fear in the audience. It is clear why this must be: tragedy is a ritual drama, and ritual drama is the drama of the gods. It usually projects man's conflict with forces that challenge his efforts to harmonise with his environment (Soyinka 1). Amadioha is that supernatural character or force in Isiburu, and because of the high importance that the playwright proposes for the supernatural personage in a tragic plot, he accords Amadioha a very large and overwhelming presence in the play. "Amadioha overshadows this verse drama" (155) writes Ebele Eko in confirmation of the god's awe-inspiring status. Amadioha's pervasive presence in the plot of the play could also be attributed to the author's original intention for the text that eventually became the play. According to Eko, "Isiburu was first conceived as an invocation to Amadioha, the most powerful god in Ikwerre land and as dear to Amadi's heart as Ogun is to Soyinka. According to Amadi, after the invocation was written, he created backwards, adding characters and details until what started as an invocation blossomed into a full verse drama, celebrating an Ikwerre wrestling hero" (155-6).

Before Amadioha's choice of him as successor to Agbarakwe, Isiburu was simply a free and pleasant character loved by all and one who enjoyed his prowess in traditional wrestling and desired to achieve the highest honour in the sport. The god's incursion into this life truncates its inherent peace and refuses to let go until the hero is finally destroyed. Thus, unlike the case of Odewale in which the gods are not to blame, Amadioha is largely to blame for Isiburu's death. Like Macbeth, Isiburu falls on the step of vaulting ambition; but unlike Macbeth's straightforward ambition, Isiburu's is ambition laced with blind and catastrophic stubbornness. True to the privilege open to an African character of negotiating the decision of the gods concerning him, Isiburu does try, at some point, to negotiate with Amadioha, but fails to win the god's approval, and the reason for the disapproval may not be farfetched: his initial approach destroys everything as it is damning. It takes the form of defiance instead of plea, and as is well known to all, the gods do not condone such impudence from mere mortals. "I tell you the time is now," announces the incumbent priest, and in response, Isiburu declares:

ISIBURU: I shall serve Amadioha Ozuzu,

But let me take this championship this year,

In the next I shall be with you

Shall man toil for six years,

And in the seventh, the harvest year,

Stay at home and fold his hands?

No, I will get the championship,

And if you cannot wait another year,

Then choose another successor. (Isiburu 6, my emphasis) 
The gods, they say, are wise. Amadioha is wise: he recognizes that Isiburu in the above statements is referring to him and not to Agbarakwe as the mortal pretends to do. "It is clear to four-eyed dibias / And to ordinary people as well" (7) that the choice of his priest is Amadioha's and not Agbarakwe's. Thus, when Isiburu says "No, I will get the championship / And if you cannot wait another year / Then choose another successor", he is obviously referring to the god and not the man.

This utter recklessness and blatant insubordination sets in motion the god's anger against the hero thus making him turn deaf ears to the hero's later adjustments toward civility, for soon after his rebellion against the god, Isiburu switches to pleading and something in the mould of a bait on the god:

ISIBURU: [Kneeling and looking up.]

Then king of thunder and of the skies

Forgive me and have patience

While I seek the championship

For which you have given me strength,

I rebel not-

No one can against you

I seek to lift your name

$[\ldots]$

ISIBURU: [Solemnly and still kneeling]

It is said that among the gods

You excel in feats of strength,

You must understand therefore how I feel;

Give me one year, just one year,

And you will have the services of a champion. (Isiburu 7-8)

It is possible that the god could have overlooked Isiburu's insubordination had he gone ahead to do the divine bidding after failing to get the god's approval for a shift in take-off date. Isiburu's resolve to carry on with his plans despite the god's silent disapproval of it, helps to embolden the already drawn battle line between the errant hero and the fierce god. The entire scenario is, of course, Amadi's making. Isiburu's rebellion is geared towards generating the kind of conflict that will climax in a fall of the hero that is capable of leaving the audience gripped with terror arising from the inexorable power of the gods, and pity out of their love for the fallen hero, their hero.

Significant also is the god's refusal to inflict immediate punishment on the offender. He waits for the one year demanded by the hero and after he has actualized the same ambition that triggered the conflict in the first place. A less discerning reader could interpret this one-year silence by the god as a sign that he fell for the 
hero's bait. Consequently, the hero's temporary death becomes a means by which the god saves himself possible disloyalty from human loyalists who could have concluded that he has grown weak. While this point of view may be valid in some right, it is, however, more accurate and rewarding to adjudge that Amadioha never succumbed to the hero's bait. Killing the hero at his point of glory is the best way to show the extent of the god's anger against the offender and that the god cannot be enticed with vain mortal glory. Besides, most offended gods relish punishing human offenders when they are most gullible - at the point when they are enjoying the fruits of their labour. This is one attitude that has earned the gods among the Igbo of eastern Nigeria and their neighbours the popular metaphor Ogbu onye mgbe ndu na-ato ya, "He that kills one at the point when one relishes living" (Kamalu and Ngwoke 10). Indeed, Amadioha is ogbu onye mgbe ndu na-ato ya. He kills Isiburu at the very point when life and living are to become most enjoyable to him. This is the period immediately following Isiburu's success at the seventh year championship when, according to the enraged Uzo:

His heart will rest now.

He has crowned his seven-year scheme

With the eagle feathers of success.

The village will build him a house

Out of communal sweat;

The best maiden, plump and sweet,

Protected for months in the confinement room,

Cared for by proud anxious parents,

Will now be his

For nothing. (Isiburu 19)

The death of such a people's hero at the very peak of his success naturally elicits the audience's pity whether the death be considered deserved or not; but the pity increases when the hero's death is undeserved. Isiburu's death is somewhat undeserved because he neither doubted Amadioha's choice of him as priest nor declined service to the god, but simply demanded a deferment.

By killing Isiburu, Amadioha proves that the gods cannot fall for mere human baits, and that their choice of a votary is neither a sentimental nor political affair, but a purely divine procedure; that the choice of Isiburu by Amadioha had nothing to do with his earthly achievements, but with those qualities of his "dearest to the heart of Amadi[oha]" (Eko 156). Of course, the friction between Isiburu and Amadioha is the kind of scenario that Amadi considers suitable for a tragic plot and which he prescribes for tragedians. It would also be recalled that Amadi, among his prescriptions cited earlier, states that "[...] in practical living, in drama and fiction, we must allow that now and then events move beyond our control and freedom of action 
appears illusory" (69). Consequently, Isiburu's insistence on getting the championship instead of immediately taking up the divine role is a clear indication of one of those times when events moved beyond his control.

While Amadi may have successfully dramatized in this tragic play his prescription on the supernatural, the unresolved issue becomes whether the hero's fall in the play is inexplicable, mysterious or associated with the supernatural, and whether these have imbued the play's denouement with the requisite fear-inducing atmosphere. The answer to this is not far-fetched: Isiburu's fall is inexplicable and mysterious; it is associated with the supernatural, Amadioha. Accounting for the inexplicability and mysteriousness of Isiburu's death is its occurrence in his tightly fortified shrine through the smashing of his highly protected Pot of Life by a mere slave boy. The scene is quite revealing of the mystery and the role of Amadioha in it:

ISIBURU: Uzo, come here!

[Uzo tries but cannot]

Oh, I forgot the invisible barrier,

Erected when the Pot was hung up.

How did you get in?

[Uzo opens his mouth but cannot talk]

That barrier was proof against any man

But a mere slave has broken through.

[Laughs hysterically then stares intently at the sky]

Amadioha king of thunder and of skies

Your hand is in this.

I have striven to bring you victory,

But you have cursed my efforts.

Worse, you have taken my life.

It is well. (Isiburu 22)

To a great extent, therefore, Uzo, like Isiburu, is not acting entirely out of his own volition. At the instance of his seeming loss of Mgbeke to Isiburu, Uzo's becomes a mercenary in Amadioha's army against their common enemy. Hence, his role in killing Isiburu is at once a mark of divine punishment and of vengeance because Uzo thought Isiburu had sacrificed Mgbeke at Eluanyim. Amadioha simply cashed in on Uzo's jealousy, and his own role was to imbue the embattled fellow with the requisite strange powers to overcome the obstacles en route the Pot of Life. There could, therefore, be no controversy as to the possibility of the above kind of death eliciting fear in the audience because it is strange, shrouded in spirituality and charms, and connected with such a dreaded god as Amadioha Ozuzu.

Isiburu's mysterious death marks the play's tragic end. His resurrection, on the other hand, re-enforces Amadi's belief in the power and influence of the supernatural 
over man. The author's high perception and, in fact, reverence and admiration for supernatural forces has already been emphasized, and in this last scene of the play he celebrates it through the elaborate and dramatic invocation of Amadioha staged by Agbarakwe flanked by some elders. The play, we have been told, was originally meant as an invocation to the god, but when turning the invocation into a play, Amadi simply assigns the religio-cultural activity a dramatic role that enables him to emphasize his long held opinion concerning the relationship between gods and humans, and his proposal to tragedians concerning paying attention in their works to our interactions with a greater power than we can contradict.

Another possible significance of the hero's resurrection is that the playwright uses it to demonstrate the already noted African gods' benevolence to their human protégées; their willingness to dialogue with their human subjects; and their openness to amendments and reparation - the qualities supposedly lacking in European gods. The process for the actualization of these obviously must be initiated by the mortals who are usually at the receiving end of the gods' decisions and actions including wrath; and the method is of course a plea, for no man can challenge his chi (god) to a battle. Here then lies the significance of the elaborate invocation whose response incidentally benefits both the people and the god. The people benefit from the return of their beloved hero who was suddenly cut down in his prime under mysterious and supposedly undeserved circumstances; the god benefits, firstly, in the form of continual reverence from his mortal protégées as the hero's revival helps to re-enforce the belief that Amadioha's "choice is so definite and irrevocable" (Isiburu 7) and, secondly, in the prospect of enjoying the services of a champion.

\section{Conclusion}

This article has, among other things, tried to handle two important issues concerning the dynamism of the literary enterprise with specific reference to tragedy and tragic aesthetics as well as their implications for the African milieu and the persuasions of one of Africa's leading writers, Elechi Amadi. First, the article has re-examined Amadi's fresh critique of Aristotle's ancient aesthetics on tragedy; and second, it has appraised the writer-critic's only tragic play based on a blend of his emergent divergent views and the rest of the Aristotelian precepts. The aspects of the Aristotelean tragic aesthetics that Amadi called into question are those that relate to a tragic hero's flaw and the expected emotional effects of the hero's tragic fall on the audience. Amadi's problem with Aristotle has been the philosopher's association of the tragic hero's fall with an error of character and his insistence that the fall of the hero based on this flaw is likely to elicit pity and fear in the audience. Part of what this article has done is to showcase Amadi's interrogation of Aristotle in this regard especially his insistence, contrary to the philosopher, that while a fall that is based on a mere flaw of character may elicit pity in the audience, it definitely will not incite 
fear in them since that fall was imminent and predictable rather than mysterious or associated with a supernatural power.

The article has thus established that Amadi, in a bid to demonstrate his deviation from Aristotle and proposal to tragedians, created in Isiburu an all-important, powerful and dreaded supernatural character whose role is interlaced with that of the hero to the extent that the supernatural became a mastermind of the hero's actions, which included the exercise of his flaw, and of course his fall. The involvement of the supernatural element in the hero's fall, true to Amadi's proposal, makes it mysterious, and this would instill the requisite fear in the audience. Furthermore, there is the dramatization of the playwright's admiration of the unmatchable power of the gods and a demonstration of his age-long philosophy of man's powerlessness in the face of superior supernatural might and the idea that man has neither the freedom of choice nor of action.

The article concludes that Amadi has demonstrated in the essay and play examined here that there is no body of literary aesthetics that is set in stone, just as it is absurd to consider any pool of aesthetic principles as universally applicable. Every set of criteria for literary creation and criticism should rather be considered as a foundation upon which novel and perhaps even more exciting ideas could be built either because of natural human advancements or of the exigencies of cultures and traditions other than that which gave it birth.

\section{Works Cited}

Amadi, Elechi. "Gods and Tragic Heroes." Speaking and Singing: Papers and Poems. U of Port Harcourt P, 2003, pp. 62-9.

. "Isiburu." Collected Plays. Edited by Seiyifa Koroye. Association of Nigerian Authors, 2014, pp. 3-38.

Aristotle. Poetics. Trans. Michael Heath. Penguin, 1996.

Césaire, Aimé. La tragédie du roi Christophe: Théâtre. Présence Africaine, 1966.

Chinyowa, Kennedy C. "The Context, Performance and Meaning of Shona Ritual Drama." Pre-colonial and Post-Colonial Drama and Theatre in Africa. Eds. Lokangaka Losambe and Devi Sarinjeive. Africa World Press, pp. 3-13.

Eko, Ebele. Elechi Amadi: The Man and His Work. Pearl, 2014.

Etherton, Michael. The Development of African Drama. Africana, 1982.

Gwynn, R. S. DRAMA: A Pocket Anthology. $4^{\text {th }}$ ed. Penguin, 2009.

Kamalu, Ikenna and Omeh Obasi Ngwoke. "A Metaphorical View of God, the Gods and the Supernatural Among the Igbo of Eastern Nigeria." African Identities vol. 15, 2017, pp. 1-13. DOI: https://doi.org/10.1 080/14725843.2017.1278585.

Maduakor, Obi. Wole Soyinka: An Introduction to His Writing. HEBN, 1991.

Miller, Arthur. "Tragedy and the Common Man." Tragedy: Vision and Form. $2^{\text {nd }}$ ed. Ed. Roberts Corrigan. Harper, 1981, pp. 744-6.

Muir, Kenneth. "Tragedy." Encyclopedia of Literature and Criticism. Eds. Martin Coyle et al. Gale Research, 1990, pp. 363-74.

Osofisan, Femi. "The Master of Suspense." Elechi Amadi at 55: Poems, Short Stories and Papers. Eds. W. Feuser and Ebele Eko. Heinemann, 1994, pp. 32-4.

Reiss, Timothy J. “Using Tragedy Against Its Makers: African and Caribbean Instances." A Companion to Tragedy. Ed. Rebecca Bushnell. Blackwell, 2005, pp. 505-36. 
Sidney, Philip. A Defence of Poetry. Oxford U P, 1966.

Sofola, 'Zulu. The Artist and the Tragedy of Nation. Caltop, 1994.

Soyinka, Wole. Myth, Literature and the African World. Canto Edition. Cambridge U P, 1990.

Wali, Obi. "Elechi Amadi-His Life and Times." Elechi Amadi at 55: Poems, Short Stories and Papers. Eds. W. Feuser and Ebele Eko. Heinemann, 1994, pp. 80-8. 